Research article

Open Access

\title{
The influence of MMP-14, TIMP-2 and MMP-2 expression on breast cancer prognosis
}

\author{
Bernard Têtu1,2, Jacques Brisson ${ }^{3}$, Chang Shu Wang², Hélène Lapointe ${ }^{2}$, Geneviève Beaudry², \\ Caty Blanchette ${ }^{3}$ and Dominique Trudel ${ }^{1}$
}

\author{
1Department of Pathology, Laval University, Québec, Canada \\ ${ }^{2}$ Centre de Recherche en Cancérologie, Laval University, Québec, Canada \\ 3Unité de Recherche en Santé des Populations, Laval University, Québec, Canada \\ Corresponding author: Bernard Têtu, bernard.tetu@chuq.qc.ca
}

Received: 3 Jun 2005 Revisions requested: 17 Aug 2005 Revisions received: 22 May 2006 Accepted: 23 May 2006 Published: 15 Jun 2006

Breast Cancer Research 2006, 8:R28 (doi:10.1186/bcr1503)

This article is online at: http://breast-cancer-research.com/content/8/3/R28

(C) 2006 Têtu et al.; licensee BioMed Central Ltd.

This is an open access article distributed under the terms of the Creative Commons Attribution License (http://creativecommons.org/licenses/by/2.0), which permits unrestricted use, distribution, and reproduction in any medium, provided the original work is properly cited.

\begin{abstract}
Introduction Matrix metalloproteinase (MMP)-2 is very active at degrading extracellular matrix. It is under the influence of an activator, membrane type 1 MMP (MMP-14), and the tissue inhibitor of metalloproteases (TIMP)-2. We hypothesized that the individual expression of these three markers or their balance may help to predict breast cancer prognosis.
\end{abstract}

Methods MMP-2, MMP-14 and TIMP-2 expression has been evaluated by $35 \mathrm{~S}$ mRNA in situ hybridization on paraffin material of 539 breast cancers without distant metastasis at diagnosis and with a median follow-up of 9.2 years.

Results MMP-2 and MMP-14 mRNA was detected primarily in reactive stromal cells whereas TIMP- 2 mRNA was expressed by both stromal and cancer cells. Of the three molecules, an adjusted Cox model revealed that high MMP-14 mRNA $(\geq 10 \%$ cells) alone predicted a significantly shorter overall survival ( $p=$ 0.031 ) when adjusted for clinical factors (tumor size and number of involved lymph nodes). Prognostic significance was lost when further adjusted for Her-2/neu and urokinase-type plasminogen activator $(p=0.284)$. Furthermore, when all three components were analyzed together, the survival was worst for patients with high MMP-2/high MMP-14/low TIMP-2 (5 year survival $=60 \%$ ) and best with low MMP-2/low MMP-14/high TIMP-2 (5 year survival $=74 \%$ ), but the difference did not reach statistical significance $(p=0.3285)$.

Conclusion Of the MMP-14/TIMP-2/MMP-2 complex, MMP-14 was the factor most significantly associated with the outcome of breast cancer and was an independent factor of poor overall survival when adjusted for clinical prognostic factors, but not for certain ancillary markers.

\section{Introduction}

In breast cancer, matrix metalloproteinase (MMP)-2 is a protease produced essentially by stromal cells. In vitro studies have clearly demonstrated that it degrades molecules that are abundant in the extracellular matrix (ECM) [1]. MMP-2 is also one of the major targets of recently developed synthetic MMP inhibitors $[2,3]$. However, recent literature demonstrates that the mechanism of action of MMP-2 is complex and that other molecules modulate its activity $[4,5]$.

MMP-2 is secreted in an inactive pro-enzymatic form and, unlike other MMPs, its activity is modulated by tissue inhibitor of metalloproteases (TIMP)-2 [6] and the membrane type 1
MMP (MMP-14) [7]. Using zymography, breast cancers were found to express higher levels of activated MMP-2 than benign lesions $[8,9]$ and in vitro studies showed that activated MMP2 only is associated with an aggressive potential in breast cancer cell lines [10].

Animal studies showed that carcinoma cell lines transfected with MMP-14 produced higher levels of active MMP-2 and developed more lung metastases compared to parent tumor cells [11]. TIMP-2 inhibits most if not all activated MMPs and was shown to form a complex specifically with pro-MMP-2 [12]. However, the role of TIMP-2 is ambiguous since, in addition to its inhibitory effect, it is a main player in the MMP-2

$\mathrm{bp}=$ base-pair; $\mathrm{ECM}=$ extracellular matrix; $\mathrm{HSP}=$ heat-shock protein; $\mathrm{MMP}=$ matrix metalloproteinase; $\mathrm{OS}=$ overall survival; $\mathrm{TIMP}=$ tissue inhibitor of metalloproteases; uPA = urokinase-type plasminogen activator. 
activation cascade [13]. However, clinical studies on breast cancer are rare, limited in size and do not address the potential interaction of all three factors (MMP-2, MMP-14 and TIMP-2).

This prompted us to test the hypothesis that the individual expression or the balance between MMP-2, MMP-14 and TIMP-2 expression may help to predict breast cancer prognosis.

\section{Materials and methods Population}

The patients included in this study had node-positive or nodenegative disease proven by histological examination of axillary lymph nodes, but with absence of distant metastases at diagnosis. The surgery for breast carcinoma was performed between 1 January 1980 and 31 December 1986. Clinical information was obtained from the patients' charts by experienced research nurses. The tumor size, and number of examined and positive lymph nodes were obtained from the pathology reports. The histological types along with the histological and nuclear grades were reassessed by one of us (BT). The project has been approved by the Laval University Ethical Review board.

\section{In situ hybridization}

MMP-2, MMP-14 and TIMP-2 expression was analyzed by in situ hybridization. The technique used was a modification of the method of Wolf and colleagues [14] as described before [15]. S 35 labeled antisense RNA probes were used. Plasmids were kindly provided by the late Prof. Paul Basset, IGBMC, Illkirch, France (MMP-2 and MMP-14) and the late Dr Anna Kossakowska, Calgary, Alberta (TIMP-2). cDNA inserts were prepared from breast cancer cDNA libraries, subcloned in pBluescript II (MMP-2 and MMP-14) and pBS KS- (TIMP-2) vectors and were used as templates for in vitro transcription to generate sense and anti-sense probes. The 2,124 base-pair (bp) MMP-2 cDNA was subcloned in the EcoRI site and extended from nucleotide 26 to 2,150; the 1,159 bp MMP-14 cDNA was subcloned in the EcoR1 site and extended from nucleotide 454 to 1,613; and the 210 bp TIMP-2 cDNA was subcloned in the HindIII/BamH1 site. Reduction of the probe length was achieved by partial alkaline hydrolysis. The quality of RNA preservation has been assessed with the use of antisense RNA probes for $\beta$-actin and negative controls were obtained with the use of sense probes. In situ hybridization for MMP-11 and urokinase-type plasminogen activator (uPA) were performed on all cases as previously described [15].

\section{Immunohistochemistry}

In addition to in situ hybridization, an immunohistochemical study was performed using the avidin-biotin complex (ABC) method as described before [15]. Studies were performed using primary antibodies to cathepsin D (Novocastra, Newcastle, UK; dilution, 1/200), p53 (Signet Labs, Dedham, MA, USA; ID labs, London, Ontario, Canada; dilution, 1/50), the heat-shock protein of $27 \mathrm{kDa}$ (HSP-27, Hu27, Dr Jacques Landry, Hôtel-Dieu de Québec, Canada; dilution, 1/200), and HER-2/neu (Triton Biosciences, Alameda, CA, USA; dilution, $1 / 15)$. For each antibody, positivity was defined by the presence of at least $10 \%$ of cells expressing the marker. P53 expression was nuclear, HER-2/neu was membranous and HSP-27 was cytoplasmic.

\section{Flow cytometry}

DNA flow cytometric analysis was performed in all cases on formalin fixed-paraffin embedded tissues using the method described by Dressler and colleagues [16]. Ploidy and Sphase fraction were determined on single parameter histograms with the use of ModFit ${ }^{\circledR}$ (Verity Software House Inc., Topsham, ME, USA). Debris were excluded with the use of the 'Single Cut' algorithm. G0, G1 and G2 M were defined from a Gaussian curve while S-phase fraction was evaluated with the trapezoid model. All cases with a coefficient of variation exceeding $8 \%$ were excluded; the coefficient of variation averaged $6.1 \%$ (range $2.5 \%$ to $8.0 \%$ ).

\section{Hormone receptors}

Estrogen and progesterone receptor measurement was obtained from the patient charts. In the early 1980s, analyses were performed using the hydroxylapatite method [17]. Positivity was defined by hormone levels above $10 \mathrm{fmol} / \mathrm{mg}$ proteins.

\section{Interpretation}

The light microscopic interpretation of in situ hybridization was done by two of us (BT, DT) without knowledge of the clinical information. The scoring was assessed separately on cancer and stromal cells using a semi-quantitative scale similar to that used for immunohistochemistry. For each cell compartment, the percentage of cancer or stromal cells expressing the marker $(0 \%,<10 \%, 10 \%$ to $50 \%,>50 \%)$ was evaluated on the whole tumor surface of one representative section.

\section{Statistical analysis}

Distant-metastasis-free and overall survival (OS) curves were obtained for each protease according to Kaplan and Meier [18]. The difference between the curves was assessed using the log-rank test [19]. Correlation between protease expression and other recognized prognostic variables in breast cancer was determined by the Chi-square test [19]. Distantmetastasis-free and OS curves were generated using $10 \%$ as the cutoff point between those expressing low (negative) or high (positive) protease levels by stromal cells, as defined before $[15,20]$. The Cox proportional hazard model was used to evaluate the relationship between the expression of each protease, or a combination of more than one protease, and recurrence or death, adjusting for other known or suspected prognostic factors [21]. Hazard ratios for the occurrence of distant metastases or death of patients with any of the above 


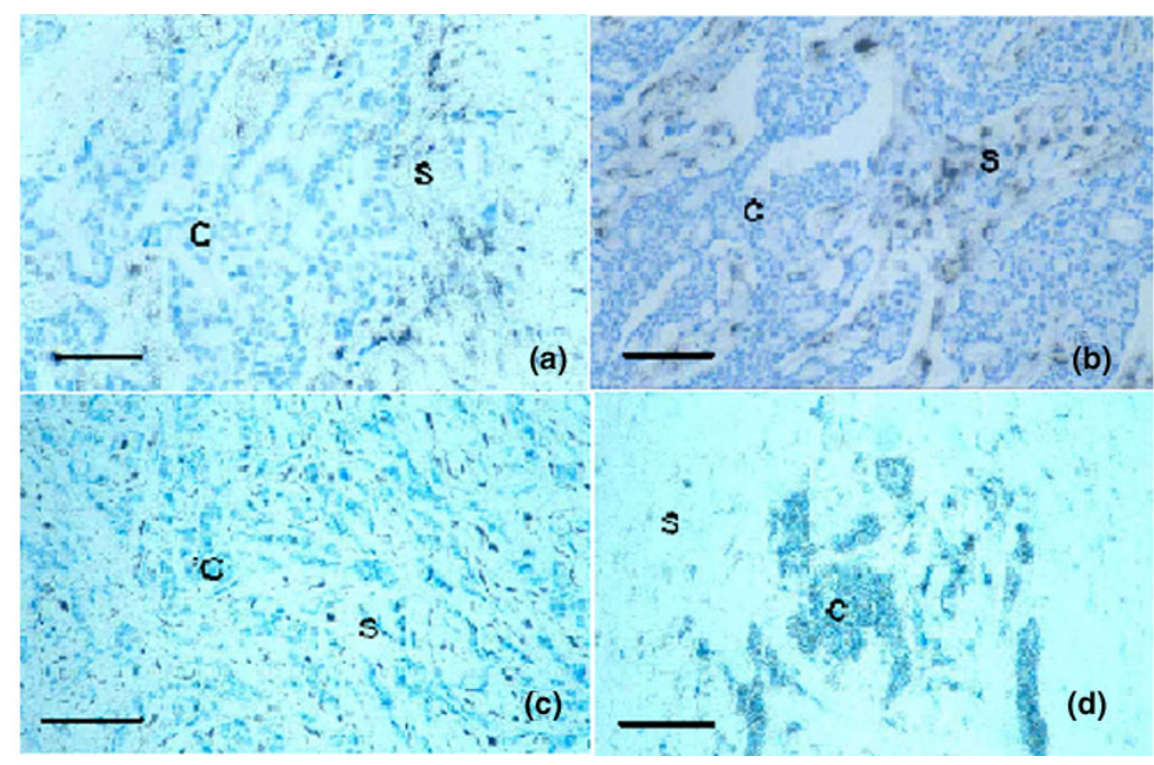

Expression of matrix metalloproteinase (MMP)-2, MMP-14 and tissue inhibitor of metalloproteases (TIMP)-2 in stromal and cancer cells. (a) MMP-2 expression by stromal cells (in situ hybridization, $\times 200$ ); (b) MMP-14 expression by stromal cells (in situ hybridization, $\times 200$ ); (c) TIMP-2 expression by stromal cells (in situ hybridization, $\times 200$ ); (d) TIMP-2 expression by cancer cells (in situ hybridization, $\times 200$ ). Scale bar $=200$ microns. C, cancer cells; S, stromal cells.

combinations were obtained by univariate and multivariate analyses.

\section{Results}

In our tumor bank, information for MMP-2 was available from 610 breast cancers, from 544 for MMP-14 and from 549 cases for TIMP-2. Results for all three molecules were available from 539 cases and all analyses have been performed on this group of patients. The patients' ages ranged from 29 to 72 years (average, 57.3). Of these patients, 190 (35.3\%) were node-negative, $340(63.1 \%)$ had node invasion, and the node status was unknown in 9 (1.6\%). At last follow-up, 258 $(47.9 \%)$ were alive and the follow-up of surviving patients ranged from 5.2 to 14.6 years (average, 9.5 years); 21 (3.9\%) were lost to follow-up.

In this study, stromal cells expressed high MMP-2 (Figure 1a) in $263(48.8 \%)$ cases, high MMP-14 (Figure 1b) in 164 (30.4\%) cases and high TIMP-2 (Figure 1c) in 200 (37.1\%) cases. Furthermore, high TIMP-2 expression by cancer cells (Figure 1d) was present in $225(41.7 \%)$ cases while cancer cells expressed MMP-14 in $4(0.7 \%)$ cases and none expressed MMP-2.

MMP-14 expression by stromal cells was significantly associated with a younger age, lymph node involvement, a ductal histology, HER-2/neu overexpression, and cathepsin D, MMP-11 (stromelysin-3) and uPA expression by stromal cells (Table 1). MMP-2 expression by stromal cells was associated with lymph node involvement, ductal histology, HER-2/neu and HSP-27 overexpression as well as cathepsin D, MMP-11 and UPA expression by stromal cells. TIMP-2 expression by stromal cells was associated with a ductal histology, and expression of HSP-27 and uPA. TIMP-2 expression by cancer cells was associated with peritumoral lymphovascular invasion, and expression of HSP-27, cathepsin D and uPA by stromal cells.

Figure 2 shows the OS curves for each of the three proteases. MMP-2 and MMP-14 expression by cancer cells was not evaluated because too few cases expressed those markers. No difference in OS was found between high and low MMP-2 and between high and low stromal and cancer TIMP-2 expression. However, high MMP-14 expression by stromal cells predicted a shorter survival $(p=0.05)$. In fact, the 5 year survival reached $72.2 \%$ for patients whose tumors had low MMP-14 levels as opposed to $64.6 \%$ for those with high MMP-14 levels. By multivariate analysis, using the Cox model adjusting for tumor size and number of involved lymph nodes, high MMP-14 expression was clearly a significant factor of poor survival (Table 2). The statistical significance was lost when HER-2/neu and UPA were included in the model. A trend was found for the association of MMP-14 expression and metastasis-free survival $(p=$ 0.08 ). Indeed, the 5 year metastasis-free survival was $64.0 \%$ for patients with low MMP-14 as opposed to $54.3 \%$ for those with high MMP-14.

Figure 3 shows the overall survival curve considering the balance between MMP-2, MMP-14 and TIMP-2. Of the different combinations, OS was worst for those patients with high stromal MMP-2/high stromal MMP-14/low stromal TIMP-2 (60.3\% survival at 5 years) and best with low stromal MMP-2/low stromal MMP-14/high stromal TIMP-2 (74.4\% survival at 5 years). 
Breast Cancer Research Vol 8 No 3 Têtu et al.

Table 1

Association of high protease expression by stromal cells with other prognostic factors

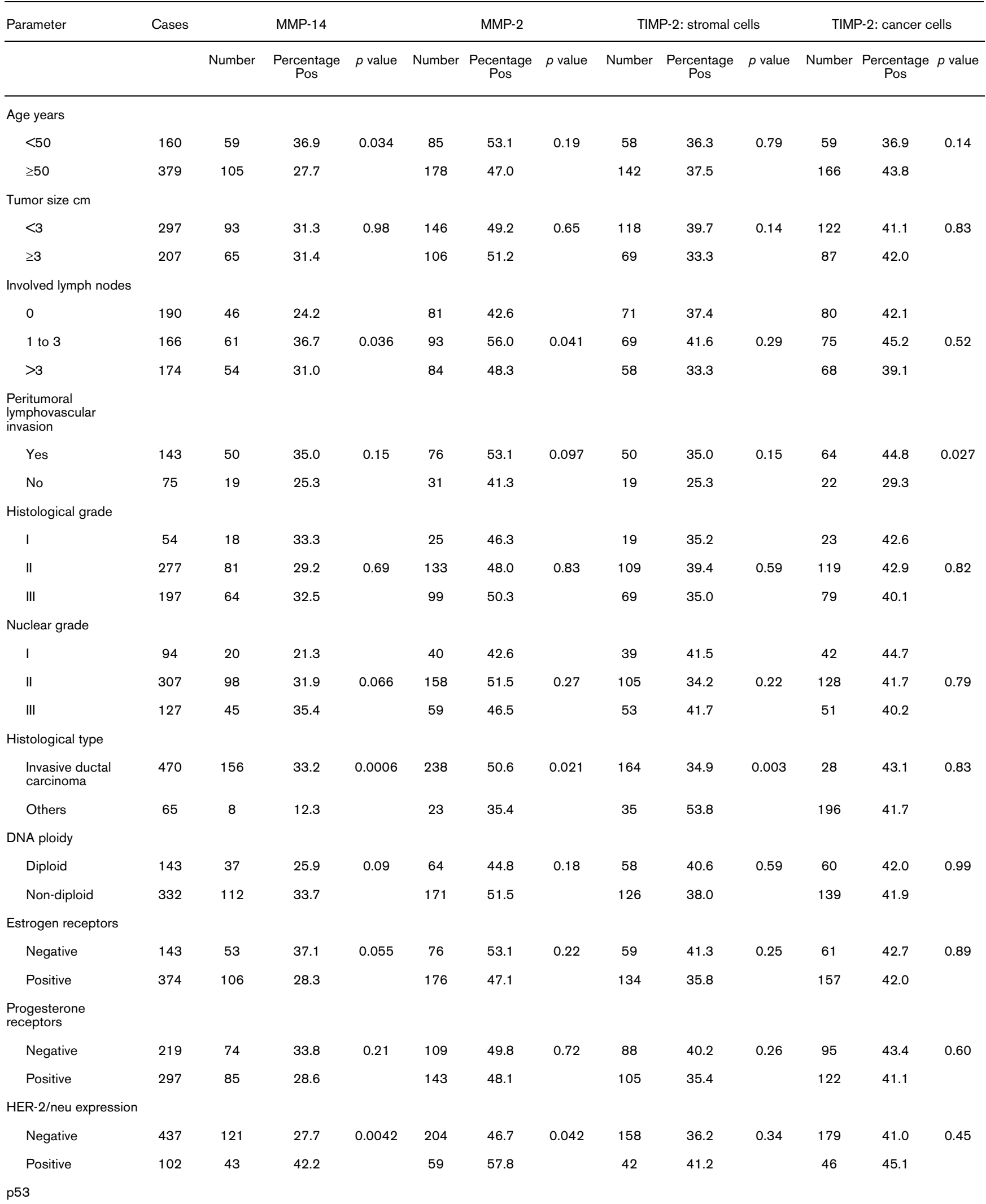


Table 1 (Continued)

\begin{tabular}{|c|c|c|c|c|c|c|c|c|c|c|c|c|c|}
\hline Negative & 374 & 107 & 28.6 & 0.12 & 186 & 49.7 & 0.53 & 132 & 35.3 & 0.24 & 149 & 39.8 & 0.30 \\
\hline Positive & 152 & 54 & 35.5 & & 71 & 46.7 & & 62 & 40.8 & & 68 & 44.7 & \\
\hline \multicolumn{14}{|l|}{ HSP-27 } \\
\hline Negative & 204 & 61 & 29.9 & 0.097 & 97 & 47.5 & 0.02 & 63 & 30.9 & 0.0024 & 70 & 34.3 & 0.0003 \\
\hline Positive & 157 & 60 & 38.2 & & 94 & 59.9 & & 73 & 46.5 & & 84 & 53.5 & \\
\hline \multicolumn{14}{|c|}{$\begin{array}{l}\text { Cathepsin D cancer } \\
\text { cells }\end{array}$} \\
\hline Negative & 324 & 94 & 29.0 & 0.29 & 151 & 46.6 & 0.21 & 111 & 34.3 & 0.071 & 127 & 39.2 & 0.102 \\
\hline Positive & 207 & 69 & 33.3 & & 87 & 52.2 & & 87 & 42.0 & & 96 & 46.4 & \\
\hline \multicolumn{14}{|c|}{$\begin{array}{l}\text { Cathepsin D stromal } \\
\text { cells }\end{array}$} \\
\hline Negative & 303 & 78 & 25.7 & 0.0035 & 130 & 42.9 & 0.0013 & 106 & 35.0 & 0.21 & 116 & 38.3 & 0.047 \\
\hline Positive & 226 & 85 & 37.6 & & 129 & 57.1 & & 91 & 40.3 & & 106 & 46.9 & \\
\hline \multicolumn{14}{|l|}{ MMP-11 } \\
\hline Negative & 215 & 32 & 14.9 & $<0.0001$ & 65 & 30.2 & $<0.0001$ & 76 & 35.3 & 0.46 & 93 & 43.3 & 0.60 \\
\hline Positive & 322 & 132 & 41.0 & & 198 & 61.5 & & 124 & 38.5 & & 132 & 41.0 & \\
\hline \multicolumn{14}{|l|}{ MMP-2 } \\
\hline Negative & 276 & 41 & 14.9 & $<0.0001$ & - & - & & 89 & 32.2 & 0.017 & 110 & 39.9 & 0.36 \\
\hline Positive & 263 & 123 & 46.8 & & - & - & & 111 & 42.2 & & 115 & 43.7 & \\
\hline \multicolumn{14}{|l|}{ uPA } \\
\hline Negative & 374 & 81 & 21.7 & $<0.0001$ & 147 & 39.3 & $<0.0001$ & 127 & 34.0 & 0.016 & 143 & 38.2 & 0.017 \\
\hline Positive & 160 & 81 & 50.6 & & 115 & 71.9 & & 72 & 45.4 & & 79 & 49.4 & \\
\hline
\end{tabular}

HSP, heat-shock protein; MMP, matrix metalloproteinase; Pos, positive; TIMP, tissue inhibitor of metalloproteases; uPA, urokinase-type plasminogen activator.

This difference did not, however, reach significance $(p=$ 0.25).

\section{Discussion}

This study confirms the complexity of the role of proteases on breast cancer prognosis. However, the prognostic influence of MMP-2 expression is not clear in the literature. TalvensaariMattila and colleagues [22], Sivula and colleagues [23] and Pacheco and colleagues [24] are among the few investigators who demonstrated a significant association between high MMP-2 mRNA or protein expression levels and a poor outcome. In our study of close to 600 cases, MMP-2 overexpression predicted a $15 \%$ greater risk of recurrence [15] but the association of MMP-2 expression with prognosis was not statistically significant. Other studies have failed to relate MMP-2 expression to a poorer prognosis $[2,15,25]$. These data are consistent with the complexity of the biology of MMP-2. In our study, they may also be explained in part by the fact that in situ hybridization cannot differentiate between the active and inactive forms.

In our study, when each factor was taken separately, and after adjustment for clinical prognostic factors, only MMP-14 was a significant factor of survival, suggesting that MMP-14 may be one of the key steps in tumor invasion and metastasis. However, the prognostic significance of MMP-14 was not independent of HER-2/neu and UPA. This finding can be explained by the strong regulatory interaction between HER-2/neu, uPA and MMPs [26]. Indeed, HER-2/neu was found to induce uPA expression and to directly up-regulate MMP expression via transcription factor-binding sites [26].

However, the association of MMP-14 but not MMP-2 expression with survival may be explained by the fact that MMP-14 has many substrates other than MMP-2. Indeed, in vitro and clinical studies support the major role played by MMP-14 on ECM remodeling. MMP-14 acts either directly by degrading ECM components such as type III collagen or indirectly by activating pro-MMP-2 and also by inducing highly vascularized tumors through vascular endothelial growth factor (VEGF) upregulation [27-30]. MMP-14 also induces functional activation of the integrin $\alpha \mathrm{V} \beta 3$, which binds to MMP-2 and increases vitronectin-mediated adhesion and migration of MCF7 cells [31]. Among prior clinical studies, high MMP-14 mRNA expression was an independent factor of both tumor invasion and lymph node metastasis in carcinoma of stomach [32], lung [33] and cervix [34]. In breast cancer, highest expression of MMP-14 by 
Figure 2
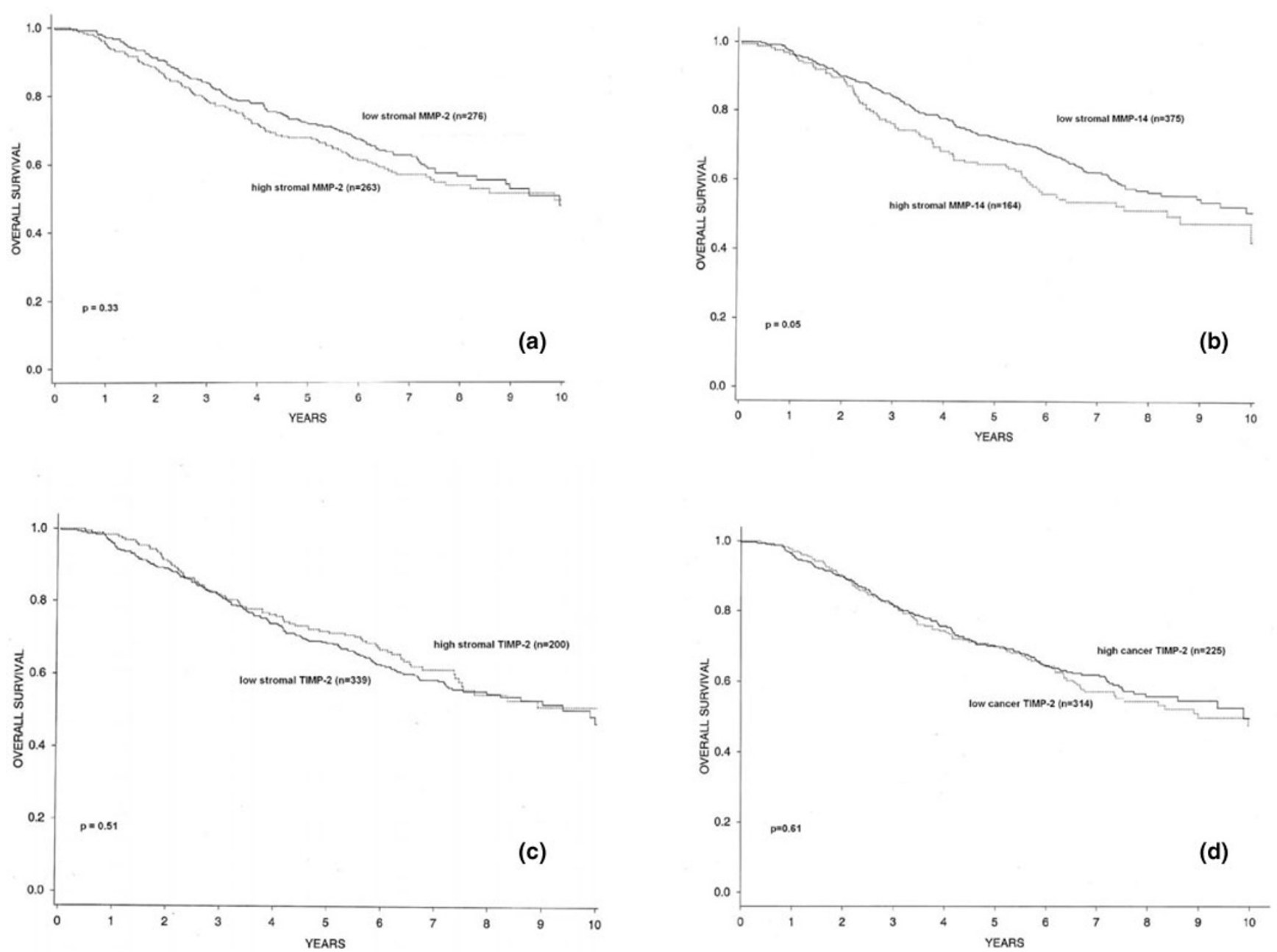

Overall survival for matrix metalloproteinase (MMP)-2, MMP-14 and tissue inhibitor of metalloproteases (TIMP)-2 expression by stromal and cancer cells. Overall survival curves for: (a) matrix metalloproteinase (MMP)-2 expressed by stromal cells; (b) MMP-14 expressed by stromal cells; (c) tissue inhibitor of metalloproteases (TIMP)-2 expressed by stromal cells; and (d) TIMP-2 expressed by cancer cells ( $p$ values obtained by the log-rank test).

Table 2

Hazard ratios for MMP-14, MMP-2, TIMP-2 and combination of MMP-14 MMP-2 TIMP-2 on breast cancer overall survival

\begin{tabular}{|c|c|c|c|c|c|c|c|c|c|}
\hline & \multicolumn{3}{|c|}{ Univariate } & \multicolumn{3}{|c|}{ Multivariate $^{\mathrm{a}}$} & \multicolumn{3}{|c|}{ Multivariate ${ }^{\mathrm{b}}$} \\
\hline & $\mathrm{HR}$ & $95 \% \mathrm{Cl}$ & $p$ value & $\mathrm{HR}$ & $95 \% \mathrm{Cl}$ & $p$ value & $\mathrm{HR}$ & $95 \% \mathrm{Cl}$ & $p$ value \\
\hline MMP-14 & 1.31 & $0.99-1.72$ & 0.05 & 1.36 & $1.03-1.81$ & 0.031 & 1.18 & $0.87-1.59$ & 0.28 \\
\hline MMP-2 & 1.14 & $0.88-1.47$ & 0.33 & 1.14 & $0.87-1.49$ & 0.34 & 0.98 & $0.73-1.31$ & 0.87 \\
\hline TIMP-2: stromal cells & 0.91 & $0.69-1.19$ & 0.51 & 1.04 & $0.78-1.38$ & 0.79 & 0.89 & $0.66-1.19$ & 0.43 \\
\hline TIMP-2: cancer cells & 1.07 & $0.83-1.39$ & 0.61 & 1.09 & $0.83-1.43$ & 0.53 & 1.02 & $0.77-1.34$ & 0.91 \\
\hline MMP-14-/MMP-2-/TIMP-2+c & 1.0 & & & 1.0 & & & & & \\
\hline MMP-14+/MMP-2+/TIMP-2- & 1.46 & $0.89-2.38$ & 0.13 & 1.29 & $0.77-2.16$ & 0.33 & & & \\
\hline Other categories & 1.11 & $0.76-1.63$ & 0.59 & 1.03 & $0.68-1.55$ & 0.90 & & & \\
\hline
\end{tabular}

aCox model adjusting for tumor size and number of involved lymph nodes. b Cox model adjusting for tumor size, number of involved lymph nodes, HER-2/neu and urokinase plasminogen activator. cTIMP-2 by stromal cells. Cl, confidence interval; HR, hazard ratio; MMP, matrix metalloproteinase; TIMP, tissue inhibitor of metalloproteases. 
RT-PCR was found in cases with lymph node metastases $[35,36]$, poor clinical stage and larger tumor size [36].

In our study, MMP-14 mRNA was located in reactive stromal cells close to cancer cells. This is consistent with data from the literature [37] that identified MMP-14 mRNA within myofibroblasts [38]. However, the location of MMP-14 in breast tissue is debated and others found MMP-14 mRNA in cancer cells [39]. Using immunohistochemistry, MMP-14 was located within either stromal and/or cancer cells [40-43].

In our study, TIMP-2 did not provide independent prognostic information. In the literature on breast cancer, the role of TIMP2 was controversial. This may explain contradictory results in which patients with higher TIMP-2 expression either experienced low cancer recurrence/progression $[44,45]$ or a poor prognosis [25,46-49], emphasizing the overall activating or inhibitory role of TIMP-2. These contradictory findings may be explained by the versatile role of TIMP-2 [12]. Indeed, TIMP-2 increases growth rates of murine, bovine and human cells [50], but also inhibits tumor growth and angiogenesis in melanoma B16F10 cells [51], attenuates migration of MDAMB23 breast cancer cells through a bone marrow fibroblast monolayer [52] and abolishes the tumor-promoting effect of fibroblasts on MCF7 cells injected with matrigel in nude mice [53].

The relationship of survival with the combination of MMP-2, MMP-14 and TIMP-2, although not statistically significant, showed that survival was worst for those patients with high MMP-2/high MMP-14/low TIMP-2 and best with low MMP-2/ low MMP-14/high TIMP-2. This lack of statistical significance may be explained by the sample size, which may be too small to reach significance, or by the versatile role of TIMP-2, which may be either a favorable or an unfavorable factor. Different combinations of proteases and protease inhibitors or activators have been investigated in the literature but clinical studies are limited and involve few patients. Clinical studies suggest that TIMP-2, or the ratio of MMP-2 and TIMP-2 expression, may play a critical role on cancer progression. For example, higher MMP-2/TIMP-2 ratios were associated with recurrences in patients with bladder [54] or uterine cervix [55] cancer. In a study on 14 patients, Onisto and colleagues [56] report that a high MMP-2/TIMP-2 ratio correlated with lymph node metastases in breast cancer while it predicted a better outcome in another study [25].

\section{Conclusion}

Our data show that, of the three proteases studied, MMP-14 was most strongly associated with breast cancer prognosis but was not independent of HER-2/neu or uPA, which may limit its usefulness as a prognostic marker. When all three proteases are studied in combination, a tendency was found for tumors with high MMP-2, high MMP-14 and low TIMP-2 expression to predict a poor prognosis but the results did not reach significance.
Figure 3

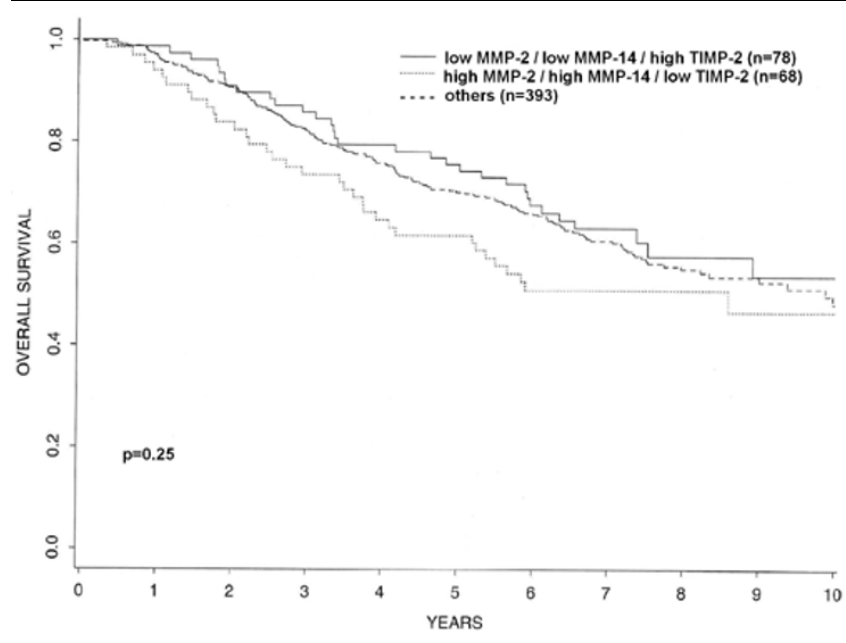

Overall survival curves for: matrix metalloproteinase (MMP)-2, MMP-14 and stromal tissue inhibitor of metalloproteases (TIMP)-2 ( $p$ values obtained by the log-rank test).

\section{Competing interests}

The authors declare that they have no competing interests.

\section{Authors' contributions}

BT, JB, CSW, and DT participated in the design of the study. CSW, $\mathrm{HL}$ and GB developed and prepared all in situ hybridization analyses. BT and DT interpreted all in situ hybridization slides. JB supervised the statistical analysis, which was carried out by CB. All authors participated to the discussion on the significance of the results, the drafting of the manuscript and approved the final version.

\section{Acknowledgements}

Sources of support: project supported by the Cancer Research Society Inc. Data base has been raised through a grant from the National Cancer Institute of Canada with funds from the Canadian Cancer Society, the Canadian Breast Cancer Foundation and a joint program from the 'Fonds de la Recherche en Santé du Québec' and Hydro-Québec. Dr Têtu was recipient of a research clinical scholarship of the 'Fonds de la Recherche en Santé du Québec' when he completed this project.

\section{References}

1. Visse $\mathrm{R}$, Nagase $\mathrm{H}$ : Matrix metalloproteinases and tissue inhibitors of metalloproteinases: structure, function, and biochemistry. Circ Res 2003, 92:827-839.

2. Brown PD, Giavazzi R: Matrix metalloproteinase inhibition: a review of anti-tumour activity. Ann Oncol 1995, 6:967-974.

3. Vihinen $\mathrm{P}$, Kahari VM: Matrix metalloproteinases in cancer: prognostic markers and therapeutic targets. Int J Cancer 2002, 99:157-166.

4. Sternlicht MD, Werb Z: How matrix metalloproteinases regulate cell behavior. Annu Rev Cell Dev Biol 2001, 17:463-516.

5. Bigg HF, Morrison CJ, Butler GS, Bogoyevitch MA, Wang Z, Soloway $\mathrm{PD}$, Overall CM: Tissue inhibitor of metalloproteinases-4 inhibits but does not support the activation of gelatinase $A$ via efficient inhibition of membrane type 1-matrix metalloproteinase. Cancer Res 2001, 61:3610-3618.

6. Stetler-Stevenson WG, Brown PD, Onisto M, Levy AT, Liotta LA: Tissue inhibitor of metalloproteinases-2 (TIMP-2) mRNA 
expression in tumor cell lines and human tumor tissues. $J$ Biol Chem 1990, 265:13933-13938.

7. Deryugina El, Ratnikov B, Monosov E, Postnova TI, DiScipio R, Smith JW, Strongin AY: MT1-MMP initiates activation of proMMP-2 and integrin alphavbeta3 promotes maturation of MMP-2 in breast carcinoma cells. Exp Cell Res 2001, 263:209-223.

8. Lee KS, Rha SY, Kim SJ, Kim JH, Roh JK, Kim BS, Chung HC: Sequential activation and production of matrix metalloproteinase-2 during breast cancer progression. Clin Exp Metast 1996, 14:512-519.

9. Remacle AG, Noel A, Duggan C, McDermott E, O'Higgins N, Foidart JM, Duffy MJ: Assay of matrix metalloproteinases types 1, 2, 3 and 9 in breast cancer. Br J Cancer 1998, 77:926-931.

10. Azzam HS, Arand G, Lippman ME, Thompson EW: Association of MMP-2 activation potential with metastatic progression in human breast cancer cell lines independent of MMP-2 production. J Natl Cancer Inst 1993, 85:1758-1764.

11. Tsunezuka $Y$, Kinoh $H$, Takino $T$, Watanabe $Y$, okada $Y$, Shinagawa $A$, Sato $H$, Seiki M: Expression of membrane-type matrix metalloproteinase 1 (MT1-MMP) in tumor cells enhances pulmonary metastasis in an experimental metastasis assay. Cancer Res 1996, 56:5678-5683.

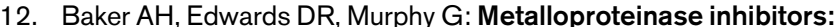
biological actions and therapeutic opportunities. I Cell Sci 2002, 115:3719-3727

13. Bachmeier BE, lancu CM, Jochum M, Nerlich AG: Matrix metalloproteinases in cancer: comparison of known and novel aspects of their inhibition as a therapeutic approach. Expert Rev Anticancer Ther 2005, 5:149-163.

14. Wolf C, Rouyer N, Lutz Y, Adida C, Loriot M, Bellocq JP, Chambon $P$, Basset $P$ : Stromelysin-3 belongs to a subgroup of proteinases expressed in breast carcinoma fibroblastic cells and possibly implicated in tumor progression. Proc Natl Acad Sci USA 1993, 90:1843-1847.

15. Têtu B, Brisson J, Lapointe H, Bernard P: Prognostic significance of stromelysin 3 , gelatinase $A$ and urokinase expression in breast cancer. Hum Pathol 1998, 29:979-985.

16. Dressler LG, Bartow SA: DNA flow cytometry in solid tumors: practical aspects and clinical applications. Semin Diagn Pathol 1989, 6:55-82

17. Erdos T, Best-Belpomme M, Bessada R: A rapid assay for binding estradiol to uterine receptor(s). Anal Biochem 1970, 37:244-252.

18. Kaplan EL, Meier P: Non-parametric estimation from incomplete observations. J Am Stat Assoc 1958, 53:453-481.

19. Armitage P: Statistical Methods in Medical Research New York: John Wiley \& Sons; 1991.

20. Têtu B, Brisson J, Côté C, Brisson S, Potvin D, Roberge N: Prognostic significance of cathepsin $D$ expression in node-positive breast carcinoma: an immunohistochemical study. Int $J$ Cancer 1993, 55:429-435.

21. Cox DR: Regression models and lifetables (with discussion). $J$ $R$ Statist Soc 1972, 34:187-220.

22. Talvensaari-Mattila A, Paakko P, Blanco-Sequeiros G, Turpeenniemi-Hujanen T: Matrix metalloproteinase-2 (MMP-2) is associated with the risk for a relapse in postmenopausal patients with node-positive breast carcinoma treated with antiestrogen adjuvant therapy. Breast Cancer Res Treat 2001, 65:55-61.

23. Sivula A, Talvensaari-Mattila $A$, Lundin J, Joensuu $H$, Haglund $C$, Ristimaki A, Turpeenniemi-Hujanen T: Association of cyclooxygenase-2 and matrix metalloproteinase-2 expression in human breast cancer. Breast Cancer Res Treat 2005, 89:215-220.

24. Pacheco MM, Mourao M, Mantovani EB, Nishimoto IN, Brentani $\mathrm{MM}$ : Expression of gelatinases $\mathrm{A}$ and $\mathrm{B}$, stromelysin-3 and matrilysin genes in breast carcinomas: clinico-pathological correlations. Clin Exp Metastasis 1998, 16:577-585

25. Nakopoulou L, Tsirmpa I, Alexandrou P, Louvrou A, Ampela C, Markaki S, Davaris PS: MMP-2 protein in invasive breast cancer and the impact of MMP-2/TIMP-2 phenotype on overall survival. Breast Cancer Res Treat 2003, 77:145-155.

26. Hsu MC, Chang HC, Hung WC: HER-2/neu represses the metastasis suppressor RECK via ERK and Sp transcription factors to promote cell invasion. J Biol Chem 2006, 281:4718-4725.

27. Ohuchi E, Imai K, Fujii $Y$, Sato H, Seiki M, Okada Y: Membrane type 1 matrix metalloproteinase digests interstitial collagens and other extracellular matrix macromolecules. $\mathrm{J}$ Biol Chem 1997, 272:2446-2451.

28. d'Ortho MP, Will H, Atkinson S, Butler G, Messent A, Gavrilovic J, Smith B, Timpl R, Zardi L, Murphy G: Membrane-type matrix metalloproteinases 1 and 2 exhibit broad-spectrum proteolytic capacities comparable to many matrix metalloproteinases. Eur J Biochem 1997, 250:751-757.

29. Pei D, Weiss SJ: Transmembrane-deletion mutants of the membrane-type matrix metalloproteinase- 1 process progelatinase $A$ and express intrinsic matrix-degrading activity. J Biol Chem 1996, 271:9135-9140.

30. Sounni NE, Devy L, Hajitou A, Frankenne F, Munaut C, Gilles C, Deroanne C, Thompson EW, Foidart JM, Noel A: MT1-MMP expression promotes tumor growth and angiogenesis through an up-regulation of vascular endothelial growth factor expression. FASEB J 2002, 16:555-564.

31. Deryugina El, Bourdon MA, Jungwirth K, Smith JW, Strongin AY: Functional activation of integrin alpha $\mathbf{V}$ beta $\mathbf{3}$ in tumor cells expressing membrane-type 1 matrix metalloproteinase. Int $J$ Cancer 2000, 86:15-23.

32. Mori M, Mimori K, Shiraishi T, Fujie T, Baba K, Kusumoto $H$ Haraguchi M, Ueo $\mathrm{H}$, Akiyoshi T: Analysis of MT1-MMP and MMP2 expression in human gastric cancers. Int $J$ Cancer 1997, 74:316-321.

33. Tsunezuka $Y$, Kinoh H, Takino $T$, Watanabe $Y$, Okada $Y$, Shinagawa $\mathrm{A}$, Sato $\mathrm{H}$, Seiki M: Expression of membrane-type matrix metalloproteinase 1 (MT1-MMP) in tumor cells enhances pulmonary metastasis in an experimental metastasis assay. Cancer Res 1996, 56:5678-5683.

34. Gilles C, Polette M, Piette J, Munaut C, Thompson EW, Birembaut $P$, Foidart JM: High level of MT-MMP expression is associated with invasiveness of cervical cancer cells. Int J Cancer 1996, 65:209-213

35. Mimori K, Ueo $\mathrm{H}$, Shirasaka C, Mori M: Clinical significance of MT1-MMP mRNA expression in breast cancer. Oncol Rep 2001, 8:401-403.

36. Ueno $H$, Nakamura $H$, Inoue $M$, Imai K, Noguchi M, Sato $H$, Seiki $\mathrm{M}$, Okada $\mathrm{Y}$ : Expression and tissue localization of membranetypes 1,2, and 3 matrix metalloproteinases in human invasive breast carcinomas. Cancer Res 1997, 57:2055-2060.

37. Polette M, Gilles C, Marchand V, Seiki M, Tournier JM, Birembaut $P:$ Induction of membrane-type matrix metalloproteinase 1 (MT1-MMP) expression in human fibroblasts by breast adenocarcinoma cells. Clin Exp Metastasis 1997, 15:157-163.

38. Bisson $\mathrm{C}$, Blacher S, Polette M, Blanc JF, Kebers F, Desreux J, Tetu B, Rosenbaum J, Foidart JM, Birembaut P, Noel A: Restricted expression of membrane type 1-matrix metalloproteinase by myofibroblasts adjacent to human breast cancer cells. Int $J$ Cancer 2003, 105:7-13.

39. Dalberg K, Eriksson E, Enberg U, Kjellman M, Backdahl M: Gelatinase $A$, membrane type 1 matrix metalloproteinase, and extracellular matrix metalloproteinase inducer mRNA expression: correlation with invasive growth of breast cancer. World I Surg 2000, 24:334-340.

40. Jones JL, Glynn P, Walker RA: Expression of MMP-2 and MMP9, their inhibitors, and the activator MT1-MMP in primary breast carcinomas. J Pathol 1999, 189:161-168.

41. Ishigaki S, Toi M, Ueno T, Matsumoto H, Muta M, Koike M, Seiki M: Significance of membrane type 1 matrix metalloproteinase expression in breast cancer. Jpn J Cancer Res 1999, 90:516-522

42. Strongin AY, Collier I, Bannikiv G, Marmer BL, Grants GA, Goldberg Gl: Mechanism of cell surface activation of 72-kDa type IV collagenase. Isolation of the activated form of the membrane metalloprotease. J Biol Chem 1995, 270:5331-5338.

43. Okada A, Bellocq JP, Rouyer N, Chenard MP, Rio MC, Chambon $P$, Basset P: Membrane-type matrix metalloproteinase (MTMMP) gene is expressed in stromal cells of human colon, breast and head and neck carcinomas. Proc Natl Acad Sci USA 1995, 92:2730-2734

44. Gorogh T, Beier UH, Baumken J, Meyer JE, Hoffmann M, Gottschlich S, Maune S: Metalloproteinases and their inhibitors: influence on tumor invasiveness and metastasis formation in head and neck squamous cell carcinomas. Head Neck 2006, 28:31-39.

45. Giannelli G, Bergamini C, Marinosci F, Fransvea E, Quaranta M, Lupo L, Schiraldi O, Antonaci S: Clinical role of MMP-2/TIMP-2 
imbalance in hepatocellular carcinoma. Int J Cancer 2002, 97:425-431.

46. Visscher DW, Hoyhtya H, Ottosen SK, Liang CM, Sarkar FH, Crissman JD, Friedman R: Enhanced expression of tissue inhibitor of metalloproteinase-2 (TIMP-2) in the stroma of breast carcinomas correlates with tumor recurrence. Int $J$ Cancer 1994, 59:339-344

47. Ruokolainen $\mathrm{H}$, Paakko $\mathrm{P}$, Turpeenniemi-Hujanen $\mathrm{T}$ : Tissue and circulating immunoreactive protein for MMP-2 and TIMP-2 in head and neck squamous cell carcinoma - tissue immunoreactivity predicts aggressive clinical course. Mod Patho/ 2006, 19:208-217.

48. Katayama A, Bandoh N, Kishibe K, Takahara M, Ogino T, Nonaka $S$, Harabuchi $Y$ : Expressions of matrix metalloproteinases in early-stage oral squamous cell carcinoma as predictive indicators for tumor metastases and prognosis. Clin Cancer Res 2004, 10:634-640.

49. Ross JS, Kaur P, Sheehan CE, Fisher HA, Kaufman RA Jr, Kallakury BV: Prognostic significance of matrix metalloproteinase 2 and tissue inhibitor of metalloproteinase 2 expression in prostate cancer. Mod Patho/ 2003, 16:198-205.

50. Hayakawa T, Yamashita K, Ohuchi E, Shinagawa A: Cell growthpromoting activity of tissue inhibitor of metalloproteinases-2 (TIMP-2). J Cell Sci 1994, 107:2373-2379.

51. Valente P, Fassina G, Melchiori A, Masiello L, Cilli M, Vacca A, Onisto M, Santi L, Stetler-Stevenson WG, Albini A: TIMP-2 overexpression reduces invasion and angiogenesis and protects B16F10 melanoma cells from apoptosis. Int J Cancer 1998, 75:246-253.

52. Saad S, Bendall LJ, James A, Gottlieb DJ, Bradstock KF: Induction of matrix metalloproteinases MMP-1 and MMP-2 by co-culture of breast cancer cells and bone marrow fibroblasts. Breast Cancer Res Treat 2000, 63:105-115.

53. Noel AC, Hajitou A, L'Hoir C, Maquoi E, Baramova E, Lewalle JM, Remacle AG, Kevers F, Brown P, Calberg-Bacq CM, Foidart JM: Inhibition of stromal matrix metalloproteases: effects on breast-tumor promotion by fibroblasts. Int J Cancer 1998, 76:267-273.

54. Gohji K, Fujimoto N, Fuji A, Komiyama T, Okawa J, Nakajima M: Prognostic significance of circulating matrix metalloproteinase-2 to tissue inhibitor of metalloproteinases-2 ratio in recurrence of urothelial cancer after complete resection. Cancer Res 1996, 56:3196-3198.

55. Nuovo GL, MacConnell PB, Simsir A, Valea F, French DL: Correlation of the in situ detection of polymerase chain reactionamplified metalloproteinase complementary DNAs and their inhibitors with prognosis in cervical carcinoma. Cancer Res 1995, 55:267-275.

56. Onisto M, Riccio MP, Scannapieco P, Caenazzo C, Griggio L, Spina M, Stetler-Stevenson WG, Garbisa S: Gelatinase A/TIMP2 imbalance in lymph-node-positive breast carcinomas, as measured by RT-PCR. Int J Cancer 1995, 63:621-626. 